\title{
LÖRINCZ Julianna
}

Selye János Egyetem, Bölcsészettudományi Kar

Magyar Nyelv és Irodalom Tanszék

Komárom, Szlovákia

jel2ster@gmail.com

\section{A PARÓDIA MINT INTRALINGVÁLIS (TEXTUÁLIS) FORDÍTÁS}

Karinthy Ady-paródiáinak és Weöres Sándor Ady szelleme mondja címü hommage-ának stílusjellemzöi

\section{The Parody as Intralingual (Textual) Translation}

Stylistic markers of Karinthy's Ady parodies and of Sándor Weöres' homage: Ady's spirit is speaking

\section{Parodija kao intralingvalni (tekstualni) prevod}

Stilske karakteristike Adijeve parodije Karintija i omaža Šandora Verě̌a pod naslovom „Adijev duh"

A szerző a dolgozat bevezetőjében a fordítás rövid meghatározásával, valamint olyan típusaival foglalkozik, amelyek az irodalmi szövegek értelmezéséhez közel(ebb) állnak, mint például az intralingvális (textuális) fordítás. Mivel a paródia fogalma nem egyértelmű a szakirodalomban, ennek definiálására a szerző sem tesz kísérletet, elfogadja azonban Umberto Eco kettős kódolás fogalmát, valamint elhelyezi a paródiát a nyelven belüli fordítások között. Ezt követően a szerző Karinthy Ady-paródiáit, valamint Weöres Sándor Ady szelleme mondja címü hommage-át elemzi a stílusimitáció szempontjából.

Kulcsszavak: intralingvális fordítás, kettős kódolás, paródia, hommage 


\section{Bevezetés}

A fordítások meghatározásával, valamint tipizálásával sok szakirodalmi munka foglalkozik, ezek közül azonban csak azokat emelem ki, amelyek a témám szempontjából relevánsak. Jakobson (1969) a fordítások következő alaptípusait különbözteti meg:

1. interlingvális (nyelvek közötti, ez a tulajdonképpeni fordítás)

2. intralingvális (nyelven belüli; átfogalmazás, parafrázis)

3. interszemiotikus (jelrendszerek közötti; a mai értelemben vett intermediális fordítás: átdolgozás, adaptáció, például megfilmesítés, megzenésítés stb.).

Peter Torop (1995) az érintkező kultúráktól, a fordítandó szövegektől függöen a következő fordítástípusokat különíti el:

1. Textuális fordítás - egy adott szöveg másik szöveggé alakítása, amely egy nyelven belül is megvalósulhat. Például egy szerző azonos témára írt különböző műfajú művei, illetve azonos múfajban írt különböző szövegvariánsai. Ez a fordítástípus Jakobsonnál az intralingvális fordítás.

2. Metatextuális fordítás - egy forrásnyelvi szövegnek más nyelvi kultúrában való újraalkotása. Ilyen a múfordítás is (Popovič 1980).

3. Intertextuális forditás - a különböző nyelvű szövegek alkotásakor és újraalkotásakor a világirodalom közös toposzait használják fel a szerzők egyegy azonos témájú müben.

Ezzel kapcsolatban kell utalnunk az irodalmi fordításról való gondolkodás szemléletére is, amely szerint a különböző nyelveken született irodalmi alkotásokat az emberiség közös kultúrkincse elemeiként értelmezhetjük (SzegedyMaszák 1998). A müfordító - az eredeti szerzőhöz hasonlóan - ebből a kontinuumból vág ki egy-egy szeletet. A müfordítás tehát intertextuális fordítás is.

4. Intratextuális forditás - ugyanazt az információt ugyanannak a nyelvnek különböző elemeivel fejezhetjük ki. A szaknyelvi regisztereket felhasználó szövegtípusok mellett a paródia és a vele rokon imitatív szövegtípusok is idesorolhatók.

5. Extratextuális forditás - verbális szöveg nem verbális üzenetté alakítása, vagy nem verbálisé verbálissá, például regény filmre adaptálása (ez Jakobson interszemiotikus típusa, a mai értelemben vett intermediális fordítás). 


\section{Az intralingvális (nyelven belüli/textuális) forditás}

A fordítás terminológiájában sok a többértelmüség, amely attól is függ, hogy nyelvész vagy irodalmár kutató közelíti meg a kérdést. Umberto Eco például az értelmezést - Jakobsonnal ellentétben - nem tartja fordításnak (Eco 2012, 226).

Umberto Eco a nyelven belüli különböző átalakítási mủveletek (intralingvális interpretáció) között több típust különböztet meg, amelyek között megemlíti a paródiát is: szinonímia, definíció, parafrázis, összegzés, összefoglalás, kommentár, magyarázó széljegyzet, vulgarizálás (bonyolult információ egyszerü megfogalmazása), komplex derivátum, képzett szó, származékszó, paródia (az interpretáció extrém formája) (Eco 2009, 284, hivatkozik rá Dobos 2011, 106). Dobos Csilla - a jogi szaknyelv elemzésével foglalkozó több tanulmányában - részletesen elemzi az intralingvális fordítási típusokat (Dobos 2013, 2014). A nyelven belüli (intralingvális fordítás) célját a következőképpen magyarázza: „A [...] nyelven belüli fordítás célja gyakran az eredeti szöveg terjedelmének, formájának, stílusának, hatásának vagy funkciójának a módosítása" (Dobos 2014, 36).

\section{A paródia}

A paródia a korábbi szakirodalmakban a tréfás irodalmi utánzás müfaja, valamely müfaj, mü, stílus vagy alkotói jellemvonások komikus hatás kiváltását célzó utánzása (Fónagy 1986, 214). A paródia szerzője felnagyítja a kiválasztott alkotó domináns jegyeit, és azokat eltúlozva, sajátos nyelvi-stilisztikai eszközökkel újraalkotja. Ugyanakkor azonban a paródiaszerző az eredeti szöveg értékeit is kiemeli, ezzel pedig részt vesz az irodalmi értékközvetítésben, ez utóbbi az irodalmi kritika alapvető funkciója is (Alföldy 2003, 5; Lőrincz 2011).

Fried István a paródia és a travesztia összehasonlítása kapcsán a paródia következő típusait emeli ki:

1. A kritikai paródia általában valamely szöveg problematikusnak tartott elemeit kritizálja.

2. A polemikus paródia a szöveg szerzőjének munkáján kívül a szerzőre is irányul, és a maga nézőpontjával ütközteti a szerzőét.

3. A komikus paródia parodizált tárgyát humoros stílusban írja át (Fried 2016, 45).

A paródia fogalmának minden igényt kielégítő meghatározásához nem juthatunk el, és nem tudjuk egyértelmüen elkülöníteni a különböző utánzó, 
ironikus, kritikai múfajoktól. Mivel a szakirodalomban összefoglaló elnevezésként fordul elő, jómagam is ebben az értelemben használom a müszót (vö. még Balogh 2018).

A paródia evokáció (felidézés). Az evokációnak jellegzetes eszköze a stílus áthallása, mögöttes tartalmainak hozzáértése, felismerése útján (Szikszainé 2007, 185). A paródiaszerző az adott költő vagy mű sajátos stíluselemeinek evokációjával, ezek eltúlzásával humoros hatást is kelt.

Az irodalmi paródiák befogadójában korábban a ráismerés öröme is munkált, mivel évtizedekig ismerték vagy ismerhették az olvasók a karikírozott, utánzott szerzőket. A mai olvasók azonban nem biztos, hogy ismerik az eredeti irodalmi szövegeket, mivel egyre kevesebben olvasnak szépirodalmat. De a paródia gyüjtőfogalom alá besorolható különböző utánzó szövegeket ismerhetnek színházból, tévéből, rádióból, így, ha irodalmi paródiákat olvasnak, nem idegen az utánzó, többnyire humoros vagy ironikus beszédmód, amely a paródiának is sajátja (lehet).

Karinthy idejében sokszor éppen a paródiák irányították rá a figyelmet a parodizált szerzőkre. Ezért is tartja Hortainé Sereg Mariann a paródiát affirmációnak is:

Az affirmatív hatás pedig abból származhat, hogy egyrészt az egyes darabok poénjainak éléből értékítélet is kiolvasható, másrészt a korábban alig ismert nevek a stílusparódiákon keresztül széles körben ismertté lettek, s máig ismertek (Hortainé Sereg 2013, 185).

\section{Kettős kódolás}

A paródia fogalom megközelítésére alkalmazzák a Charles Jencks építésztől származó, az irodalomban pedig Umberto Eco által továbbfejlesztett kettös kódolás kifejezést is, amely azonban nem fogalom, hanem retorikai mủveletsor (Tarjányi 2013, 79; Eco 2004).

[...] olyan - sőt inkább több - értelemmezőre számot tartó mủvek sorolhatók ide, amelyekben az ellentmondásos kettősség gyakran az irónia modalitásával kapcsolódik össze. [...] Azonban a kettős kódolás kifejezésnek egy másik, gyüjtőfogalomként alkalmazott, a parodisztikusságot is magába foglaló, de attól mégiscsak tágabb jelentésrétege is idetartozik. [...] Az ilyen jellegủ müvek egyszerre múködtetik a hagyományos kódrendszert, megfelelve a kor olvasói szokásainak és elvárásai- 
nak, ugyanakkor rejtetten egy másik olvasási lehetőségre is felhívják a figyelmet, amely ugyan megjelenhet parodisztikus átírás formájában, de a paródián túlmutató másfajta lehetőségek is idesorolhatók, amelyek az irodalmi jelhasználat többszörös értelemmezeje felé irányítják a szövegérzékelést (Tarjányi 2013, 7-9).

\section{A Karinthy-paródiák}

Így irtok ti című kötetében megjelent humoros utánzó-bíráló szövegeit Karinthy maga nem paródiáknak nevezte, hanem irodalmi torzképeknek, karikatúráknak. Karinthy paródiáit a szerző egyedi müfajának is tekinthetjük, mivel több müfaj sajátosságait ötvözi.

A Karinthy-paródiákon valójában nem a paródiamüfaj legismertebb hazai alkotásait kellene értenünk, hanem a szerző egyedi műfaját, mely egyaránt merít a travesztia, a paródia, a pastiche és a szatíra egyetemes müfaji hagyományaiból és a századfordulós divatos élclapok sajátos humorából (Bónus 2007, 847).

Karinthy Frigyes célja az Így írtok ti (1912) címü paródiagyüjteményben a parodizált írók neki nem tetsző emberi gyengeségeinek, viselkedésének, világnézetének karikírozása mellett szövegeik legjellemzőbb stílusjegyeinek kiemelése, utánzása. A Karinthy-paródia stílusimitáció, másképpen stílusköziség, az utánzás egyik formája, amelynek során egy szövegben úgy jelenik meg az utánzott szerző vagy szöveg stílusa, hogy a befogadó számára az eredeti szöveg stílusával együtt válik értelmezhetővé (Pethő 2016, 35; Tolcsvai Nagy 1996, 173-74).

A paródia tárgyának azonosíthatósága minden esetben feltétele a paródia működésének, minthogy a paródia befogadásának esszenciális összetevője a tárgyra való ráismerés. Ennek hiányában a paródia befogadása téves, inadekvát, hiszen a paródia müfaji alapfunkciója szenved csorbát (Kappanyos-Sereg 2010, 78).

\section{Az Ady-paródiák}

Ady Új versek (1906) címü kötetének megjelenése után két évvel megalapított Nyugat modern, „új és magyar” költői hangot hozott be az irodalmi köztudatba. Míg azonban a folyóirat szerkesztöi és az írótársak Ady stílusát irányadónak tekintették, egyes kortárs szerzők és a közvélemény egy része Ady 
nyelvét érthetetlennek, szókimondását sértőnek, erkölcstelennek, magyarságtudatát pedig gőgnek tartotta.

Ady stílusának egyik domináns jellemzője a szimbólumok, szimbólumrendszerek alkalmazása. Fónagy Iván fontos stílusjegyként említi a szimbólumok tartalmi vonatkoztatásait, ugyanakkor megállapítja, hogy a szimbólumok használata jellemezheti a költői életmü irányváltozását is (Fónagy 1999, 297). Ady nem elszigetelt szimbólumokat, hanem egész szimbólumrendszereket alkot, amelyek teljes költészetét kohezív erőként átszövik, tehát az egész költői életmüre kiható meghatározó jelentésképző szerepük van. Ady szimbólumhasználatára jellemző, hogy képrendszereinek építőelemei ambivalensek: külön nem vagy nehezen értelmezhetők (Lőrincz 2011, 150-151).

Ady szimbólumrendszerének legfontosabb elemei Karinthy Ady-paródiáiban is megjelennek. „A paródiák müvészi eszközeit áttekintve az ismétléseket, a váratlan degradációt, a különféle motívumok átvételét, a túlzást [...] és más efféléket emleget (a szakirodalom) [közbevetés tőlem - L. J.], végül is az olvasóra gyakorolt hatás szerint minősíti a Karinthy-darabokat" (Büky 2003, 69). Ady szövegeinek meghatározó stilisztikai alakzatai az ismétlések, ellentétek, párhuzamok. Sokszor alkalmaz merész szemantikai ellentéteket, mint például A magyar Ugaron címủ versének szövegében. Ady legjellemzőbb szimbólumai változatlan vagy motivikus ismétlésként szinte egész költői életművében jelen vannak. Hiába keresnénk azonban a Karinthy-paródiák eredetijét egy szerző egyetlen szövegében, csak a költői életmü egészében találhatjuk meg.

Ady legjellemzőbb stílusjegyeinek imitációját a Moslék-ország címü Karinthy-paródia elemzésével mutatom be!

Ady Endre: Moslék-ország

(Megjelent német és francia fordításban is)

Jött értem a fekete hajó,

Jött értem a fekete vizen.

Álom-királyfit vitt, tova vitt

Moslék-országnak mentiben -

Fekete hajó, fekete vizen.

Moslék-ország, hajh, cudar ország,

Hajh, Hortobágy, zsir-szivü rém;

Hajh, Átok-város, Redves-ugar:

Piszok-hazám, mit kapaszkodsz belém?

Fekete vizeken jöttem én. 


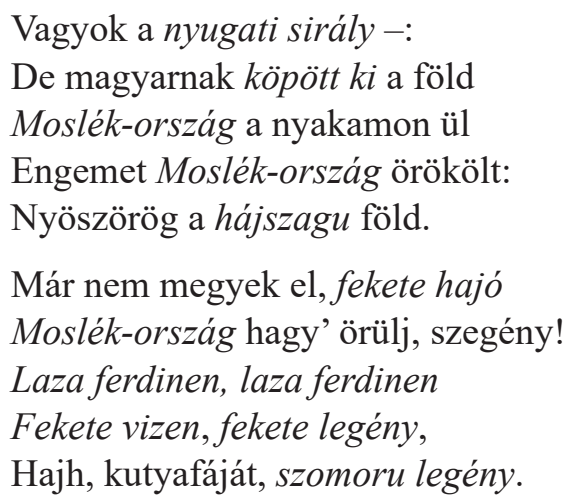

Az Ady költészetét jellemző világlátást a verseiben is sokszor használt fekete jelző (pl. A fekete zongora) változatlan ismétlésével érzékelteti Karinthy a paródiában. A hajó és a víz szimbólum ugyancsak sokszor szerepel Ady költészetében, mint például az Új vizeken járok címü versében is. Ezek a motívumok és a sajátos asszociációjú egyedi összetételek, például az álom-királyfi, mint jellemző motívumok fontos szerepet játszanak a Moslék-ország címü Karinthy-paródiában is.

Ady nemzetostorozását szintén a költőre jellemző egyéni szóösszetétellel, a pejoratív stílusértékủ moslék-országgal és a népies stílusértékü cudar jelzővel evokálja Karinthy. Az indulatszó is visszatérő stíluselem Adynál, ennek felidézésére szolgál a hajh indulatszó háromszori ismétlése.

A Hortobágy szimbólum a nyugattól elmaradt Magyarország szimbólumaként van jelen Ady költészetében, ennek megjelenése a Karinthy-versben konkrét utalás a költőnek a A Hortobágy poétája című versére. A Hortobágy, zsirr-sziviü rém kifejtett metaforában a zsír-szivü jelzős szerkezettel Karinthy nemcsak az elmaradott országra utal, hanem ezzel Ady merész vízióit is karikírozza. Az Átok-város, Redves-ugar, Piszok-hazám összetételek szinonimikus ismétléses alakzatok, melyek Ady sajátos ismétléseit idézik.

Ezekkel a pejoratív stílusértékủ szimbólumokkal adekvátak a Karinthyparódia más nyelvi elemei is, mint például a köpött ki népies kiszólás (vö. kiköpött apja). Az egyes szám első személyü névmások és igék gyakori használata, Ady saját fontosságának hangsúlyozása - vitt-engem, értem, én, belém, vagyoka paródiában Ady jellemző személyiségvonására, gőgnek tartott éntudatára utal, amelyet Karinthy nem szeretett.

Ady sajátos nyelvi kifejezőeszközeit, hapax legomenonjait utánozza Karinthy a paródiaszövegben a hájszagu metonimikus jelzővel, valamint a föld nyöszörög megszemélyesítéssel is. A laza ferdinen ismétléssel és a hajh kutyafáját 
népies kurjantással a betyárromantikát is evokálja, amelyet Ady sem szeret. A sirály önmegnevező motívumként Ady verseiben is szerepel, a nyugati jelző pedig az Ady-versekben gyakran megjelenö (vö. A magyar ugaron, A Tiszaparton), a fejlett nyugati és az elmaradt magyar élet, kultúra közti ellentét egyik pólusa, a másik pedig a magyarnak köpött ki a föld kijelentés. A laza ferdinen a német lass mich verdinen - 'hadd tünjek ki, hadd keressek pénzt' kifejezés elferdítése, amellyel a pénz mindenhatóságára utalhat (vö. Harc a Nagyúrral) (Reményi-Tarján 1994).

Az ismétlésre mint „,ingyenes redundanciára” is tekinthetünk (pl. a társalgásban a gondolkodási szünetet kitöltő vagy gondolathelyettesítő elemek), és mint funkcionális stíluseszközre is. „Franciában gratuit-nek, 'ingyenes'-nek nyilvánul mindaz, ami céltalan, indokolatlan. Az irodalmi paródiák figyelmét az 'ingyenes ismétlés' sem kerülte el. Esztétikai reakcióink azt tanúsítják, hogy az ismétlés különböző módjait nem tévesztjük össze" (Fónagy 1999, 89). Ady-szövegeiben az ismétlések többnyire nem funkciótlan stíluselemek. Karinthy a paródiáiban azonban arra utal az ismétléssel, hogy mivel gyakran alkalmazza őket Ady, a korabeli bírálók egy része funkciótlannak tartotta (vö. Törpe-fejüek címü paródia).

\section{Az hommage}

Az hommage is - a paródiához hasonlóan - utánzó müfaj, de van közöttük különbség is: az hommage tiszteletadás valamely müvész életmüve elött, amelynek a megidézett költői témákon kívül a nyelv, a stílus is része, de nem épít egyértelmủen a humorra, mint a paródia, bár humoros vagy ironikus áthallások lehetnek benne - sokszor éppen a mai befogadói értelmezésben.

(Weöres hommage-aiban) a hang, a stílus, a nyelv által teremtett szubjektivitás, a maszk ,szólal meg”, sokszor dialogikus, parodisztikus interakcióba kerülve a szöveg más szólamával, amely egyes esetekben meghatározható a hagyományos versszubjektum hangjaként is, de nem szükségszerủen azonos vele (Papp 2013, 15).

Weöres hommage-a Ady költészetének megidézése. Weöres, bár költői pályája kezdetén írói ízlésére, értékítéletére nagy hatással voltak a Nyugat több szerzőjének, többek közt Adynak a versei, azonban nem volt olyan értelemben meghatározó szerzője a Nyugatnak, mint pl. Ady vagy Babits (nem is lehetett életkoránál fogva). Azonban erősen hatott rá Ady: vagy azért, mert tetszett neki, vagy pedig ellenérzéseket váltott ki belöle. Az Ady szelleme mondja címü verse Rozsnyay Kálmán felkérésére íródott: 
[...] Amikor 1938-ban vallott róla, költészetén kívül a megváltozott befogadói elvárásokat is érintette. Szerinte - halála után alig két évtizeddel elsősorban a laikusok jelentik olvasótáborát. Azok között népszerü, akik a lírában elsősorban nem esztétikai élményt, hanem érzelmeket, szenvedélyeket keresnek (Lőcsei 2013).

Weöres Sándor: Ady szelleme mondja

«Félig-mondott, babonás álmok

forogtak bennem szakadatlan, rémek kolompja volt a nyelvem, míg fözött egy iszonyu katlan halotti torra, csemegének.

Még sustorogtam benn a Tálban, méltóan az inyenci kegyre: siess már jóllakni belőlem, mert hülök egyre, hülök egyre, kutyáké a hideg maradék.

Holtan is élve hirdetem még: ujjat se mozdíts, mert hiába, de másodszor is meghalok én és holmi új, szent bibliába ássák el kihült igéimet.

Lakj jól belölem repedésig, mert soká nem lesz lakzi, légyott, még tor se: ha éhesen maradsz, visszakéred a maradékot a rád-vicsoritó Ebektöl.

Boraitok elsavanyodnak, elkeserednek mind a kertek, a tulajdon házatok alján bolyongtok mind, csupa kivertek, még holttestem is belesajdul. Énrám pedig vigyázni fognak, hogy rólam tisztesség ne essék: idők gyomrában hült-mereven alszom majd, mint új Ó-Szövetség, kiterítve, szent ravatalon.» 
Weöres hommage-a - a Karinthy-paródiákhoz hasonlóan - szintén egyfajta esszenciáját adja Ady költészetének, nem nélkülözve az enyhe ironikus és humoros felhangot sem, de elsősorban a költőutód tisztelete szól belöle. Ennek értelmezéséhez és az Ady-szövegek témáival, stílusával való egybevetéséhez véleményem szerint nem lehet egyetlen verset kiemelni Ady költészetéből. Weöres szövegében Ady jellemző alakzatainak - ismétlés, ellentét és párhuzam - imitációját érhetjük tetten, amelyekkel azonban Ady több versszövegében is találkozhatunk.

E tanulmánynak nem célja Ady jellegzetes motívumainak kiemelése és a Weöres-szöveggel való egybevetése, mert meggyőződésem, hogy teljes megfelelést hiába is keresnénk. Részletes elemzés helyett bemutatok egy, az interneten talált 8. osztályos irodalmi feladatlapot, amely közvetlen hasonlóságot fedeztetett fel a tanulókkal Weöres hommage-a és Ady egy konkrét verse között. Az alábbi táblázatban szemléltetem, milyen motívumokra ismerhet rá Weöres Sándor $A d y$ szelleme mondja című versszövegének általános iskolás olvasója, ha tanulta Ady Emlékezés egy nyár-éjszakára címủ versét (Zanza TV, internetes forrás).

\begin{tabular}{|l|l|}
\hline $\begin{array}{l}\text { Ady Endre: } \\
\text { Emlékezés egy nyár-éjszakára }\end{array}$ & $\begin{array}{l}\text { Weöres Sándor: } \\
\text { Ady szelleme mondja }\end{array}$ \\
\hline $\begin{array}{l}\text { 1. az álom-motívum: } \\
\text { „Almomban élö volt a holt” }\end{array}$ & $\begin{array}{l}\text { „Félig-mondott, babonás álmok / } \\
\text { forogtak bennem szakadatlan” }\end{array}$ \\
\hline $\begin{array}{l}\text { 2. Az idilli világ széthullá- } \\
\text { sa: „Kigyúladt öreg méhesünk, / } \\
\text { Legszebb csikónk a lábát törte” }\end{array}$ & $\begin{array}{l}\text { „Boraitok elsavanyodnak, / } \\
\text { elkeserednek mind a kertek, / } \\
\text { a tulajdon házatok alján” }\end{array}$ \\
\hline $\begin{array}{l}\text { 3. A fenyegető (háborús) világ képi } \\
\text { megjelenítése: „véres, szörnyư } \\
\text { lakodalom” }\end{array}$ & „iszonyu katlan”; lakzi \\
\hline $\begin{array}{l}\text { 4. A rettenet képe: „Az iszonyuság a } \\
\text { lelkekre / Kaján örömmel ráhajolt” }\end{array}$ & „rémek kolompja volt a nyelvem” \\
\hline $\begin{array}{l}\text { 5. Utalás a halott életre: } \\
\text { „Valamely elhanyagolt Isten / } \\
\text { Eletre kap s halálba visz / } \\
\text { S, íme, mindmostanig itt élek” }\end{array}$ & „de másodszor is meghalok én” \\
\hline $\begin{array}{l}\text { 6. Utalás a prófétaszerep } \\
\text { hiábavalóságára: } \\
\text { „S Isten-várón emlékezem” }\end{array}$ & $\begin{array}{l}\text { „Holtan is élve hirdetem még: / } \\
\text { ués holmi új, szent bibliába / } \\
\text { ássák el kihült igéimet” }\end{array}$ \\
\hline
\end{tabular}




\begin{tabular}{|l|l|}
\hline $\begin{array}{l}\text { 7. Utalás a Bibliára, illetve az Istenre: } \\
\text { „Az Égből dühödt angyal dobolt / }\end{array}$ & $\begin{array}{l}\text {,alszom majd, mint új } \\
\text { Riadót a szomorvetség”, } \\
\text { „Azt hittem, akkor azt hittem, / }\end{array}$ \\
$\begin{array}{l}\text { Valamely elhanyagolt Isten / Életre } \\
\text { kap s halálbálba visz”, illetve: ,S Isten- } \\
\text { várón emlékent bibliába / }\end{array}$ & \\
\hline
\end{tabular}

8. osztályos irodalmi feladatlap megoldása (Zanza TV)

Ezt az összehasonlítást elsősorban azért emeltem ki, mert látható, hogy több Ady-motívum és a biblikus hangnem imitációja megtalálható a Weöresszövegben, amelyek az Emlékezés egy nyár-éjszakára címü Ady-szövegre is jellemzőek. De Ady más szövegeiben is találhatunk ehhez hasonló stíluselemeket, amelyek ismétléses, ellentétes és párhuzamos alakzat formájában jelentésképző funkciót töltenek be. Weöres szövegének jelentés- és struktúraképző alakzatai egyértelmủen felidézik Ady több témáját, hangját, mint ahogyan a Karinthy Ady-paródiák is. Az hommage alapján a versolvasók a cím ismerete nélkül is ráismernének Ady stílusára.

Ez az összehasonlítás egy alkalmazható módszer arra, hogy a magyartanár a tanulókkal ráéreztessen az Ady-szövegek jellegzetes stíluselemeire. Mint ahogyan a Karinthy-paródiák is közelebb vihetik az irodalmi szövegek olvasásában kevésbé jártas olvasókat is az Ady-versek értelmezéséhez. De természetesen már általános iskolában sem helyettesíthetik a komplexebb irodalmiszöveg-értelmezést.

\section{Összegzés}

A paródia több, imitációra építő irodalmi müfaj gyüjtőfogalmaként szerepel a szakirodalomban. Ha a nyelvészeti fordításelmélet felől vizsgáljuk, intralingvális (Jakobson) vagy textuális (Torop) fordításnak tekinthetjük. Az irodalmi szövegértelmezésben Umberto Eco kettős kódolásnak (double coding) nevezi. A kettős kódolás azonban nem paródiafogalom, hanem az irodalmi szöveg értelmezése során alkalmazható retorikai múveletek összessége.

Az irodalmi paródia mint sajátosan magyar paródiaváltozat, Karinthy Frigyes nagy sikerü irodalmi karikatúráival foglalta el az igazi helyét a magyar irodalomban. Tanulmányomban az Így írtok ti címü kötet paródiái közül azért választottam elemzésre az Ady stílusát evokáló Moslék-ország címü paródiát, mert Karinthy Ady stílusjegyeinek humoros hatást kiváltó imitációjával hozzájárult az alkotó egyéni stílusának megértéséhez is. Ady új hangot, új stílust hozott 
a magyar irodalomba. Hangzásban, zeneiségben, szó- és kifejezéskészletben, képi szinten újszerü, sajátos formák, nyelvi eszközök jelennek meg műveiben. Karinthy paródiáinak stilisztikai szempontú elemzése, valamint az alkotó eredeti szövegeinek stílusával való összehasonlítása segíthet megérteni, hogy milyen eszközökkel érte el az író saját korában azt a hatást, amelyet ma is kivált az olvasóban.

A paródia és az hommage közös jellemzője, hogy egy szerző jellemző témáit, stílusjegyeit kiemelve imitál, felidézi a szerző legjellemzőbb jelentés- és formaképző stílusjegyeit. Amíg azonban a paródia célja a szerző legjellemzőbb témáinak, személyiség- és stílusjegyeinek evokálása ironikus vagy komikus hangnemben, az hommage fó célja az utánzáson kívül a szerző előtti tisztelgés. Nem állítom ezzel, hogy Karinthy egyáltalán nem tisztelte a parodizált szerzöit. Volt, akit igen, volt, akit szeretett volna távol tartani a magyar irodalomtól.

Weöres Sándor kiemelt versszövege szintén Ady jellemző stílusjegyeit imitálja egy, a paródiához hasonló, de inkább tisztelgést, hódolatot kifejező, semmint komikus hangnemü müfajban, az hommage-ban. A vizsgált szöveg egyes motívumai, alakzatai - a Karinthy-paródiákhoz hasonlóan - evokálják Ady versbeszédének sajátos motívumait, jelentés- és stílusképző alakzatait.

\section{Irodalom}

Ady Endre háborús versei. Zanza TV. https://zanza.tv/irodalom/klasszikus-modernseg-realizmus-naturalizmusszimbolizmus-impresszionizmus-szecesszio/ady-2 (2019. febr. 20.)

Alföldy Jenő. 2003. A paródia költészete. Eső - irodalmi folyóirat 6 (2): 8-16. http:// www.esolap.hu/archive/19/488.html (2019. febr. 10.)

Balogh Gergő. 2018. A paródia mint materiális fordítás. Az Így írtok ti poétikai működésmódjának kérdéséhez. In Karinthy nyelvet ölt. Nyelv, technika és felelösség Karinthy Frigyesnél. Budapest: Fiatal Î́rók Szövetsége.

Bónus Tibor. 2007. Paródia, technika és az irodalom médiuma. In Szegedy-Maszák Mihály-Veres András szerk. A magyar irodalom történetei 2. 1800-tól 1919-ig. 839-855. Budapest: Gondolat Kiadó.

Büky László. 2003. Egy Karinthy-paródia stílusekvivalenciái. In Magyar nyelvjárások. A Debreceni Egyetem Magyar Nyelvtudományi Tanszékének évkönyve 41. 69-78. Debrecen: Debreceni Egyetem. http://mnytud.arts.unideb.hu/mnyj/41/mnyj41.pdf (2011. ápr. 30.)

Dobos Csilla. 2011. Az intralingvális fordítás sajátosságai. In Docēre et movēre-Bölcsészet- és társadalomtudományi tanulmányok a Miskolci Egyetem Bölcsészettudományi Kar 20 éves jubileumára. 101-110. Miskolc: Miskolc University Press. 
Dobos Csilla. 2013. A nyelven belüli fordítás különböző típusai. In Alkalmazott Nyelvészeti Közlemények VIII. 61-75. Miskolc: Miskolc University Press.

Dobos Csilla. 2014. A nyelven belüli fordítás néhány jellemzőjéről. In „Transfer nec mergitur”. Albert Sándor tiszteletére 65. születésnapja alkalmából. 35-44. Szeged: JATE Press.

Eco, Umberto. 2004. Az intertextuális irónia és az olvasat szintjei. In La Mancha és Bábel között. Irodalomról. 317-352. Budapest: Európa Könyvkiadó.

Eco, Umberto. 2009. Quasi dasselbe mit anderen Worten. Über das Übersetzen. München: Deutscher Taschenbuch Verlag.

Eco, Umberto. 2012. Az értelmezés nem fordítás. In Literatura 3. 225-247. http://www.balassikiado.hu/BB/NET/LITERATURA/Literatura2012_3.pdf(2019. febr. 10.)

Fónagy Iván. 1986. Paródia. In Király István főszerk. Világirodalmi lexikon X. Budapest: Akadémiai Kiadó.

Fónagy Iván. é. n. [1999]. A költői nyelvröl. Egyetemi Könyvtár. Budapest: MTA Nyelvtudományi Intézet-Corvina.

Fried István. 2016. Szövegek érintkezése a komikai térben. Jókai Mór verses travesztiái. In Irodalomtörténeti Közlemények 1. 31-46.

Hortainé Sereg Mariann. 2013. A paródia mint affirmáció: Karinthy Frigyes paródiáinak szerepe a nyugatosok népszerüsitésében. Doktori (PhD-) értekezés. Miskolc: Miskolci Egyetem BTK. http://midra.uni-miskolc.hu/document/17996/11860.pdf (2019. febr. 15.)

Jakobson, Roman. 1969. Hang - jel-vers. 372-382. Budapest: Gondolat.

Kappanyos András. 2012. Eco, a fordítás és mi. In Literatura 38 (3): 266-275.

http://www.balassikiado.hu/BB/NET/LITERATURA/Literatura2012_3.pdf(2018. nov. 10.)

Kappanyos András-Sereg Mariann 2010. Forditható-e a paródia? 78-102. https://www.tankonyvtar.hu/en/tartalom/tamop422b/20100008_kotet24_07_ kappanyos_andras_sereg_mariann_fordithato_e_a_parodia/07_kappanyos_andras_ sereg_mariann fordithato_e_a_parodia_1_1.html (2019. febr. 19.)

Karinthy Frigyes. Így írtok ti (Válogatás)

http://www.mek.iif.hu/porta/szint/human/szepirod/magyar/karinthy/igyirtok/ $\mathrm{html} /$ index.htm?utm_source $=$ mandiner\&utm_medium $=$ link\&utm_campaign= mandiner_201812 (2019. febr. 5.)

Lőcsei Péter. 2013. Weöres Sándor és a Nyugat. In Holmi jún.

http://www.holmi.org/2013/06/locsei-peter-weores-sandor-es-a-nyugat (2019. jan. 25.)

Lőrincz Julianna. 2011. Karinthy-paródiák és Ady-versek jellemző stílusjegyeinek funkcionális stilisztikai egybevetése. In Alkalmazott Nyelvészeti Közlemények 6 (1): 147-154. Miskolc: Miskolci Egyetem.

https://www.researchgate.net/publication/235496484_MezosiM_Lesprit_descalier es_az_igazsagra_valo_tor (2019. febr. 12.) 
Nagy L. János. 2003. A retorikus nyelvhasználat Weöres Sándor költészetében. Budapest: Akadémiai Kiadó.

H. Nagy Péter. 2012. Jótékony paródiák. A Karinthy-blokk elé. In OPUS (17): 5-9.

Papp Ágnes Klára. 2013. A paródia ars poeticája. Szerep és maszk Weöres Sándor költészetében. In Látó jún.

Pethő József. 2016. Weöres és Krúdy (Néhány szempont Weöres Sándor nyolcadik szimfóniájának stíluselemzéséhez. In Prózától a líráig. Írások Nagy L. János tiszteletére. 35-42. Szeged: Szegedi Egyetemi Kiadó, Juhász Gyula Felsőoktatási Kiadó.

Popovič, Anton. 1980. A müforditás elmélete. Bratislava: Madách.

Reményi József Tamás-Tarján Tamás. 1994. Magyar antológia. Jegyzetek Karinthy Frigyes Így írtok ti címü kötetéhez. Budapest: Magvető Kiadó.

Szegedy-Maszák Mihály. 1998. Fordítás és kánon. In A forditás és intertextualitás alakzatai, szerk. Kabdebó et al. 66-72. Budapest: Anonymus.

Szikszainé Nagy Irma. 2007. Magyar stilisztika. Budapest: Osiris.

Tarjányi Eszter. 2013. Arany János és a parodisztikus hagyomány. Budapest: Universitas Kiadó, Editio Princeps Kiadó.

Tolcsvai Nagy Gábor. 1996. A magyar nyelv stilisztikája. Budapest: Nemzeti Tankönyvkiadó.

Torop, Peter. 1995. Тотальный перевод (A totális fordítás). Tartu: Tartu University Press.

Weöres Sándor. 1933. Ady szelleme mondja. In Nyugat 3.

http://epa.oszk.hu/00000/00022/00551/17238.htm (2019. febr. 10.)

\section{THE PARODY AS INTRALINGUAL (TEXTUAL) TRANSLATION}

Stylistic markers of Karinthy's Ady parodies and of Sándor Weöres 'homage:

Ady's spirit is speaking

In the introduction of the paper the author is dealing with the types of translation defined by Roman Jakobson and Torop, which are close(r) to interpretation of literary texts. Since the concept of parody is not completely unambiguous in special literature, the author does not make an attempt to define it, but rather accepts Umberto Eco's concept of double coding, and she places the parody among intralingual translations. Subsequently the author analyses Ady parodies by Karinthy and the homage by Sándor Weöres entitled Ady's spirit is speaking, and compares the two texts on the basis of style imitation.

Keywords: intralingual translation, double coding, parody, homage 


\section{PARODIJA KAO INTRALINGVALNI (TEKSTUALNI) PREVOD \\ Stilske karakteristike Adijeve parodije Karintija i omaža Šandora Vereša pod naslovom „Adijev duh"}

U uvodu rada autor daje preglednu definiciju prevođenja i bavi se onim tipovima prevođenja koji su bliži interpretaciji književnih tekstova kao, na primer, intralingvalno (tekstualno) prevođenje. S obzirom na to da pojam parodije u stručnoj literaturi nije nedvosmislen, ni autor se ne trudi da ga definiše, međutim operiše pojmom dvostrukog koda Umberta Eka smeštajući parodiju među prevode unutar jezika. Autor zatim iz perspektive imitacije stila analizira Adijeve parodije Friđeša Karintija i omaž Adijev duh Šandora Vereša.

Ključne reči: intralingvalno prevođenje, dvostruki kod, parodija, omaž 